\title{
VĒSTURISKO MŪRJAVU ILGMŪŽĪBAS NODROŠINĀŠANA LATVIJAS SENATNES BŪVĒS
}

\author{
INTA KIRILOVIČA ${ }^{1 *}$, MARGARITA KARPE ${ }^{2}$, \\ INTA VĪTIN,A ${ }^{3}$, SILVIJA IGAUNE-BLUMBERGA ${ }^{4}$ \\ ${ }^{1-4}$ Rìgas Tehniskā universitāte, Latvija
}

\begin{abstract}
Kopsavilkums. Pētījumi par Latvijas kultūrvēsturisko ēku akmens materiālu koroziju kopš 1984. g. tiek veikti Rīgas Tehniskās universitātes Silikātu materiālu institūta Akmens materiālu konservācijas un restaurācijas centrā. Šie pētījumi sniedz bagātīgu materiālu krājumu un pieredzi saistībā ar senatnes būvju ilgmūžības nodrošināšanu. Katra objekta restaurācijas tehnologiijas izstrādes pamatā ir jābūt rūpīgai izpētei. Līdzšinējā pieredze ir devusi vērtīgas atziṇas par mūsdienās pieejamo javu saistvielu (portlandcementa, kal̦ku u. c.) izmantošanas nosacījumiem restaurācijas procesos.
\end{abstract}

Atslēgas vārdi - kaḷki, korozija, mūrjava, restaurācija, romāncements, saistviela, sāḷi.

\section{Ievads}

Javām būvmateriālu vidū jau kopš seniem laikiem bijusi īpaša loma: tām ir savstarpēji jāsaista citi būvmateriāli (akmens materiāli, k,ieǵel̦i), kā arī jāaizsargā namu sienu, fasāžu un dekoratīvo elementu virsma.

Kopš 13. gs. un 14. gs. piḷu un vēlāk arī citu ēku būvniecībā Latvijas teritorijā plaši lietoti kal, şi, kas iegūti no vietējā kaļ̣,kakmens un dolomìta.

Atkarībā no izejvielas (karbonātieža) veida izšķir dolomītkal̦ķu javas

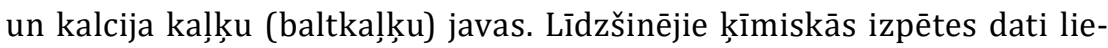
cina, ka Latvijā galvenokārt lietoti dolomītkal̦kị [1].

* Korespondējošais autors.

E-pasts: inta.kirilovica@rtu.lv 
19. gs. un 20. gs. mijā visā Eiropā plaši lietoja romāncementu. To ieguva no merǵel̦a - ieža, kas satur 15-40 \% mālu un 60-85 \% karbonātu (kal̦,kakmens vai dolomīta). Ieguve bija vienkārša - mergeli apdedzināja relatīvi zemās temperatūrās (800-1200 $\left.{ }^{\circ} \mathrm{C}\right)$ un smalki samala, iegūstot hidraulisku saistvielu, kam nebija nepieciešama veldzēšana [2].

Atšķirībā no Centrālās Eiropas, kur tika izmantots kaļ ķakmens romāncements, Latvijas teritorijā jau no 19. gs. sešdesmitajiem gadiem tika ražots dolomīta romāncements, par izejvielu izmantojot vietējo dolomītmerǵeli, kuru apdedzināja 800-900 ${ }^{\circ} \mathrm{C}$ temperatūrā. Šāds cements ir lietots daudzu Latvijā nozīmīgu vēsturisku ēku celtniecībai 19. gs. un 20. gs. mijā, piemēram, bijusī Latvijas Valsts Universitātes Ķīmijas fakultātes ēka (Kronvalda bulvāris 4, 1901. g.), Latvijas Nacionālā teātra ēka (Kronvalda bulvāris 2, 1902. g.), Latvijas Centrālās bankas ēka (Krišjāṇa Valdemāra iela 2a, 1905. g.) u. c. [3], [4], kā arī jūgendstila ēku fasāžu ornamentiem. Romāncementa priekšrocības bija ātra saistīšanās (ap 15 min), kas l̦āva no tā darināt ēku dekoratīvos rotājumus ar liešanas tehniku, liela porainība (ap 30 \%), kā arī augstā ūdensnoturība un izturība pret apkārtējās vides nelabvēlīgo ietekmi, kas noteica saistvielas piemērotību lietošanai fasādēs.

Kopš 20. gs. vidus dolomīta romāncementa ražošana Latvijā ir pārtraukta, un kultūras mantojuma restaurācijas mērksiem šì javu saistviela (romāncements) pieejama ierobežoti [5].

Vēsturisko būvjavu un apmetumu tehniskais stāvoklis Latvijas kultūrvēsturiskajos objektos nereti ir tuvu tai kritiskajai robežai, aiz kuras seko neatgriezeniska autentiskā materiāla izzušana, kas apdraud objekta turpmāko eksistenci [6], [7].

\section{Korozijas procesi}

Vēsturisko ēku bojājumu pakāpe ir atkarīga no tā, kādiem nelabvēlīgas ietekmes faktoriem tā ir pakḷauta. Viens no svarīgākajiem bojājumu izraisītājiem vēsturiskajās būvēs ir to paaugstinātais mitrums, šḳīstošo sāḷu veidošanās un ūdens migrācija. Mitrums ir priekšnoteikums gandrīz visiem ķīmiskajiem, biogēnajiem un fizikālajiem procesiem, kas izraisa akmens materiālu sabrukšanu [8].

Pilnīgi sausos būvmateriālos nav šksīstošo sāḷu izraisītu bojājumu. Ūdens ir priekšnosacījums, lai tādi rastos. Parasti pietiek ar gaisā esošo mitrumu, lai varētu novērot sāḷu izraisītos bojājumus. Tie lielos apmēros parādās tad, ja ūdenim un sāḷiem pievienojas vēl papildus apstākḷi - temperatūras un gaisa mitruma svārstības. Sāḷu graujošā iedarbība var būt saistīta ne vien ar ksīmisku reakciju starp tiem un akmens materiālu, bet arī katra apkārtējās vides (temperatūras, mitruma) izmaiṇa var izraisīt 
sāḷu kristalizēšanos vai hidratēšanos, kas parasti ir galvenie akmens materiālu sabrukšanas iemesli [6].

Sāḷu migrācijas rezultātā uz ēku sienām var parādīties kristalizējušos sāḷu zonas - izsāḷojumi. Tie pēc savas dabas ir dažādi. Ja izsāḷojumus veido kalcija karbonāts $\left(\mathrm{CaCO}_{3}\right)$, kas veidojas, $\mathrm{Ca}(\mathrm{OH})_{2}$ lietus ūdens iedarbībā pa plaisām izskalojoties no mūrjavas un pēc tam karbonizējoties, šie izsālojumi nav bīstami mūrim. Rekristalizējoties šis savienojums būtiski nepalielina tilpumu, līdz ar to nerada spriegumu materiāla porās. Tomēr $\mathrm{CaCO}_{3}$ izsālojumi var radīt kaitējumu ēkai, ja tie notek pār citiem materiāliem, piemēram, stiklu vai granītu, un piekalst pie tā. Šādā gadījumā tā notīrīšana ir l̦oti sarežǵīta un var bojāt apkārtesošos materiālus (parasti attīrīšanai nākas lietot skābi).

Bīstamākie ir gadījumi, kad izsāḷojumi satur sulfātus, hlorīdus, nitrātus. To rekristalizācija izsauc būtisku vēsturisko materiālu sairšanu [9].

Ūdens kā nesējvide migrējot poru struktūrā, veicina sāḷu nokḷūšanu mūros un izraisa k,īmisko, fizikālo un biogēno koroziju: mitruma iesūkšanos caur sienām, ūdens sasalšanas un atkušanas ciklu bojājumus, sāḷu hidratācijas un kristalizācijas bojājumus, saistvielas izskalošanos, rūsas plankumus, netīrumu piesaistīšanu, alı́gu, kērpju un sūnu veidošanos [9]. Šie procesi ir diktējuši akmens materiālu pretkorozijas aizsardzības, konservācijas un restaurācijas virziena rašanos visā pasaulē.

\section{Korozijas procesu izpēte}

Lai veiktu jebkura vēsturiskā objekta restaurāciju un konservāciju, vispirms ir nepieciešams noskaidrot vēsturiskā akmens materiāla un korozijas produktu ķīmisko sastāvu, korozijas pakāpi un fizikālās īpašības, novērtēt tā atrašanās vietu un mitruma migrāciju. Tikai pēc tam var izstrādāt pareizu konservācijas tehnologiju.

Restaurācijas praksē viens no priekšnosacījumiem ir oriǵinālam pēc iespējas līdzīga materiāla izmantošana, turklāt jānodrošina saderība ar vēsturisko materiālu tā pašreizējā, novecojušā stāvoklī [10].

Latvijā pētījumi par akmens materiālu koroziju izraisošiem faktoriem un restaurāciju uzsākti 1984. g. Rīgas Tehniskās universitātes Silikātu materiālu institūta Akmens materiālu konservācijas un restaurācijas centrā. Pareizas autentiskas restaurācijas veikšana ietver plašu pasākumu kompleksu, kam pamatā ir vēsturisko materiālu zinātniskā izpēte: k,īmiskais un granulometriskais sastāvs, struktūra, fizikālās īpašîbas, baktēriju, gruntsūdeṇu iedarbība, mitruma migrācija un objekta atrašanās vieta. Tādēl l, loti svarīgi ir katrā individuālā gadījumā veikt k,īmiskās analīzes, dokumentēšanu, virsmas bojājumu kartografēšanu un stāvokḷa novērtēšanu. Pēc ḳīmiskās analīzes datiem nosaka 
vēsturiskā mūrējumā lietoto saistvielu (dolomītkal,ḳi, baltkaḷ,ki, cements vai cita), pildvielas veidu un piesāḷojumu.

Vēsturisko saistvielu izpētei tiek lietota šāda metodika [1], [11]:

Vēsturisko mūrjavu ilgmūžības

nodrošināšana Latvijas senatnes būvēs

\section{1) Vizuālais izvērtējums, mikroskopija;}

Vizuālais izvērtējums vispirms tiek veikts ar neapbruṇotu aci - bez palīgierīcēm un pēc tam ar mikroskopa palīdzību dažādos palielinājumos. Jau pie 6 līdz 20 reižu palielinājuma iespējams gūt priekšstatu par javas saistvielas - pildvielas attiecību, pildvielas dal̦inu veidu un formu, saistvielas krāsu, porainību, kā arī gūt informāciju par dažādu piedevu klātbūtni paraugā - ķieǵel̦u smelkni, zāǵskaidām, koka dalı̣n̄ām, salmiem, dzīvnieku spalvu, ogli, kaula vai akmentinu ieslēgumiem utt. Lielākoties parauga vizuālais novērtējums ir vienkārša metode, ar kuras palīdzību ir iespējams noteikt piedevas klātbūtni, kā arī novērtēt tās aptuveno daudzumu.

\section{2) Granulometriskā analīze;}

Granulometriskā analīze ir samērā vienkārša un lēta metode. To veic, izšk̦īdinot saistvielu un pēc tam izskalotās un izžāvētās pildvielas daļinas sijājot caur sietu kolonnu. Šai analīzei nepieciešami lieli javas paraugi (parasti 50-100 g, bet dažreiz pietiek ar 20-30 g). Tas var būt problemātiski, ja vēsturiskais materiāls nav pieejams pietiekamā daudzumā. Šajā pārbaudē gūtā informācija ir izškiriroša, lai izvēlētos piemērotu pildvielu vai pildvielas-saistvielas attiecību restaurācijas javai [12].

\section{3) Klasiskā kēīmiskā analīze;}

Pilna k̦īmiskā analīze vēsturiskajām saistvielām tiek veikta saskaṇā ar silikātu materiālu klasiskās slapjās analīzes metodiku LVS EN 196-2:2013.

\section{4) Rentgenstaru difrakcijas analīze (XRD);}

XRD ḷauj identificēt vēsturisko saistvielu kristāliskās mineralogiskās fāzes, kā arī iespējamo tādu sekundāru, koroziju izraisošu mineraloǵisko fāžu klātbūtni kā šksīstošie sāḷi. Šìs analīzes priekšrocība ir ātrums un tas, ka analīzēm nepieciešams l̦oti neliels vēsturiskā materiāla paraugs. XRD ir galvenā metode, lai atšksirtu hidraulisku kal̦ ķa javu no cementa javas. Diemžēl ar šo metodi iespējams noteikt tikai tās kristāliskās fāzes, kuru daudzums lielāks par $3 \%$.

\section{5) Diferenciāli termiskā analīze un termogravimetrija (DTA/TG);}

DTA/TG līdzīgi kā XRD ir ātra un relatīvi lēta metode. Ar DTA/TG analīzes palīdzību iespējams iegūt informāciju ne tikai par javu fāžu sastāvu, bet arī par katras noteiktās fāzes daudzumu. Atseviškās situācijās DTA/ TG var pat aizvietot dārgo un laikietilpīgo ksīmisko analīzi, tomēr, kā jau minēts, DTA/TG datu interpretācijai nepieciešama pieredze un iemaṇas.

\section{6) Fizikālo (hidrisko) īpašību pārbaude;}

Raksturot javas fizikālās īpašîbas (veikt hidriskos mērījumus) iespējams tikai tad, ja pieejams pietiekami liels vēsturiskā materiāla paraugs (ne mazāk kā aptuveni 100 g, turklāt mehāniski noturīgs). Brīvā un 
piespiedu ūdens uzsūce, kā arī žūšanas dinamika tiek noteikta, izmantojot standartmetodes [12]. Iegūtos datus izmanto, lai aprēksinātu materiāla blīvumu, porainību un poru savstarpējo savienotību. Šì informācija nepieciešama ne tikai, lai raksturotu parauga fizikālās īpašības, bet arī, lai izstrādātu atbilstošu restaurācijas javu, jo abu īpašībām jābūt tik līdzīgām, cik vien iespējams. Šì informācija nepieciešama arī, lai veiktu atbilstošā vēsturiskā materiāla nostiprinātāja vai konservanta izvēli. Fizikālās īpašības parasti tiek mērītas arī restaurācijas javu paraugiem, bet, izvēloties piemērotāko restaurācijas līdzekli, arī apstrādātiem un neapstrādātiem javas paraugiem [1], [11].

I. tabula

Vēsturisko mūrjavu k̦īmisko analīžu rezultāti, masas \%

\begin{tabular}{|c|c|c|c|c|c|c|}
\hline \multirow{3}{*}{ 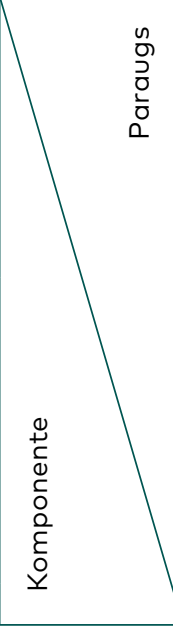 } & \multicolumn{3}{|c|}{ 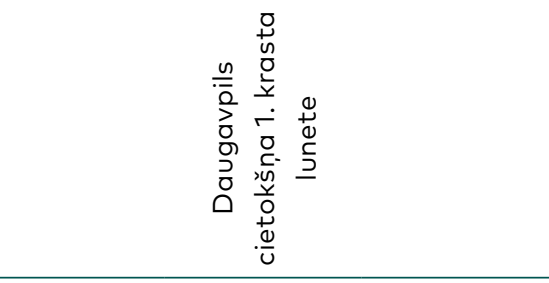 } & \multicolumn{3}{|c|}{ 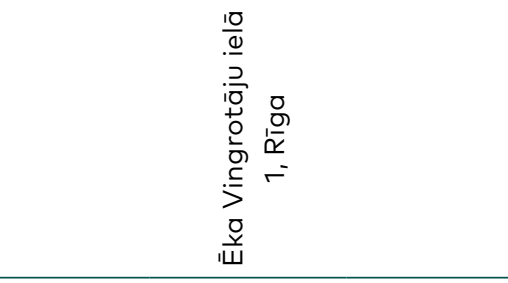 } \\
\hline & 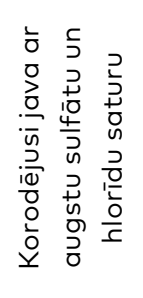 & 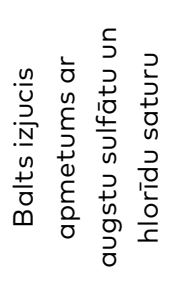 & 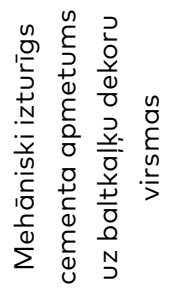 & 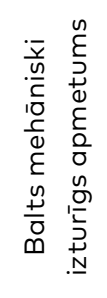 & 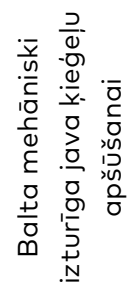 & 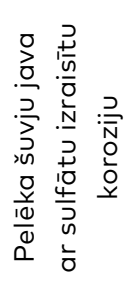 \\
\hline & 1 & 2 & 3 & 4 & 5 & 6 \\
\hline $\begin{array}{c}\text { Karsēšanas } \\
\text { zudumi, } \\
1000^{\circ} \mathrm{C}\end{array}$ & 27,29 & 27,04 & 14,21 & 13,20 & 11,44 & 30,60 \\
\hline $\begin{array}{l}\text { Nešḳis- } \\
\text { tošais } \\
\text { atlikums }\end{array}$ & 41,84 & 52,61 & 62,73 & 68,81 & 72,12 & 35,44 \\
\hline $\mathrm{CaO}$ & 16,04 & 12,09 & 16,56 & 9,59 & 10,01 & 19,37 \\
\hline $\mathrm{MgO}$ & 9,60 & 7,90 & 0,72 & 3,76 & 2,86 & 9,43 \\
\hline $\mathrm{SiO}_{2}$ akt. & 1,36 & 0,31 & 1,17 & 2,80 & 2,26 & 1,61 \\
\hline $\mathrm{Al}_{2} \mathrm{O}_{3}$ & 1,20 & 0,89 & 2,13 & 1,05 & 0,97 & 1,08 \\
\hline $\mathrm{Fe}_{2} \mathrm{O}_{3}$ & 0,65 & 0,33 & 0,53 & 0,34 & 0,28 & 0,56 \\
\hline Kopā & 97,92 & 98,17 & 98,05 & 99,55 & 99,71 & 97,77 \\
\hline $\mathrm{CaO} / \mathrm{MgO}$ & 1,67 & 1,53 & 23,0 & 2,55 & 3,50 & 2,05 \\
\hline $\begin{array}{l}\text { Saistvielas } \\
\text { pildvielas } \\
\text { attiecība }\end{array}$ & $1: 1,4$ & $1: 2,3$ & $1: 2,7$ & $1: 3,8$ & $1: 4,4$ & $1: 1$ \\
\hline
\end{tabular}


Restaurācijas javas sastāva izstrāde iespējama, veicot vēsturiskā Vēsturisko mūrjavu materiāla īpašību izpēti, skat. I. tabulu un II. tabulu. Saistvielas, pildvielas un piedevu izvēles pamataspekti ir šādi:

1) saistviela tiek izstrādāta, balstoties uz ksīmisko, XRD un DTA/TG analǐžu rezultātiem;

2) pildviela, kā arī pildvielas-saistvielas attiecība tiek noteikta, galvenokārt balstoties uz paraugu vizuālo izvērtējumu un gravimetriskā sastāva analīzes datiem;

3) piedevas tiek noteiktas balstoties uz ķīmiskās analīzes datiem un parauga vizuālo novērtējumu [13].

\begin{tabular}{|c|c|c|c|c|}
\hline 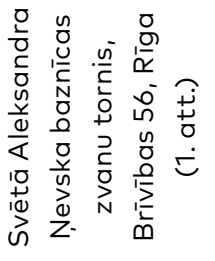 & 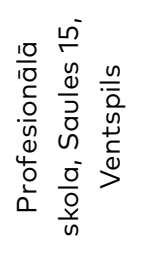 & 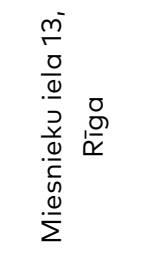 & 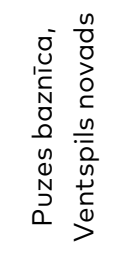 & 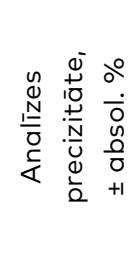 \\
\hline 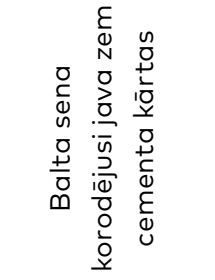 & 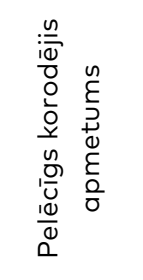 & 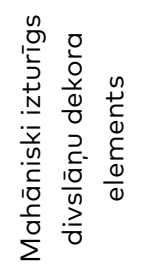 & 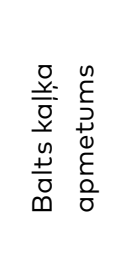 & \\
\hline 7 & 8 & 9 & 10 & - \\
\hline 8,62 & 10,10 & 14,13 & 44,05 & 0,3 \\
\hline 80,46 & 72,87 & 45,23 & 11,45 & 0,5 \\
\hline 7,03 & 8,05 & 24,92 & 42,20 & 0,5 \\
\hline 1,96 & 3,38 & 3,36 & 1,71 & 0,5 \\
\hline 0,68 & 4,20 & 6,04 & 0,37 & 0,3 \\
\hline 0,45 & 0,76 & 4,09 & 0,44 & 0,3 \\
\hline 0,19 & 0,38 & 1,07 & 0,21 & 0,1 \\
\hline 99,37 & 99,74 & 98,84 & 100,43 & - \\
\hline 3,5 & 2,38 & 7,4 & 24 & - \\
\hline $1: 7$ & $1: 4$ & $1: 0,8$ & $1: 0,25$ & - \\
\hline
\end{tabular}


Aprēḳinātais sākotnējās saistvielas ḳimiskais sastāvs, masas \%

\begin{tabular}{|c|c|c|c|c|c|c|c|c|c|c|c|}
\hline Paraugs & 1 & 2 & 3 & 4 & 5 & 6 & 7 & 8 & 9 & 10 & $\begin{array}{c}\text { Analīzes } \\
\text { precizitāte, } \\
\pm \text { absol. \% }\end{array}$ \\
\hline $\mathrm{CaO}$ & 51,9 & 51,8 & 71,8 & 53,4 & 60,9 & 57,0 & 64,4 & 47,1 & 61,4 & 90,3 & 0,5 \\
\hline $\mathrm{MgO}$ & 31,0 & 33,8 & 3,1 & 20,9 & 17,4 & 27,8 & 17,9 & 19,8 & 8,3 & 3,8 & 0,5 \\
\hline $\mathrm{SiO}_{2}$ akt. & 4,4 & 1,3 & 6,1 & 15,6 & 13,7 & 4,7 & 6,2 & 24,5 & 14,9 & 0,8 & 0,5 \\
\hline $\mathrm{Al}_{2} \mathrm{O}_{3}$ & 3,9 & 3,8 & 9,2 & 5,8 & 5,9 & 3,2 & 4,1 & 4,4 & 10,1 & 1,0 & 0,5 \\
\hline $\mathrm{Fe}_{2} \mathrm{O}_{3}$ & 2,1 & 1,4 & 3,3 & 1,8 & 1,7 & 1,6 & 1,7 & 2,2 & 2,6 & 0,4 & 0,1 \\
\hline $\begin{array}{c}\mathrm{SiO}_{2}+\mathrm{Al}_{2} \mathrm{O}_{3}+ \\
\mathrm{Fe}_{2} \mathrm{O}_{3}\end{array}$ & 16,4 & 6,5 & 18,6 & 23,2 & 21,3 & 9,5 & 12,1 & 31,1 & 27,6 & 2,2 & - \\
\hline $\begin{array}{l}\text { Hidrauliskuma } \\
\text { modulis }(h m)\end{array}$ & 8,0 & 13,1 & 4,5 & 3,19 & 3,7 & 8,9 & 6,8 & 2,13 & 2,45 & 41 & - \\
\hline $\begin{array}{l}\frac{n}{0} \\
\frac{0}{0} \\
> \\
n \\
\frac{n}{0} \\
\frac{0}{2} \\
\frac{0}{0} \\
\frac{0}{0} \\
0\end{array}$ & \multicolumn{2}{|c|}{ 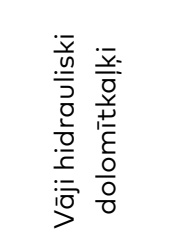 } & 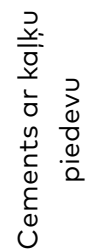 & \multicolumn{2}{|c|}{ 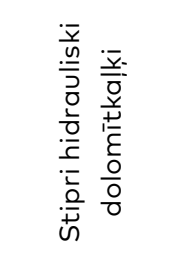 } & \multicolumn{2}{|c|}{ 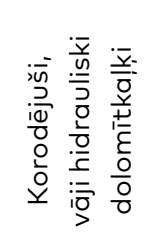 } & 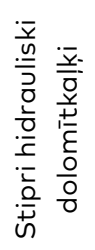 & 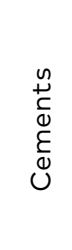 & 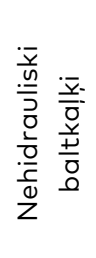 & ' \\
\hline
\end{tabular}

Novērtēt izraudzīto restaurācijas sastāvu ir sarežgi îts uzdevums, jo tam jāatbilst vizuāli, kā arī pēc kīmiskajām, fizikālajām un mehāniskajām īpašībām.

Apkopotie kultūrvēsturisko objektu mūrjavu k̦īmisko analīžu rezultāti parāda, ka līdz mūsu dienām labāk saglabājušies vēsturiskie mūri, kuru būvniecībā lietotas hidrauliskas javu saistvielas, kuru izejvielu sastāvā bijis optimāls mālvielu saturs, kas nodrošināja hidraulisko piedevu $\mathrm{Al}_{2} \mathrm{O}_{3}, \mathrm{Fe}_{2} \mathrm{O}_{3}$ un aktīvā $\mathrm{SiO}_{2}$ klātbūtni. Šādas saistvielas ir hidrauliski dolomîtkal, ki un romāncements, kā arī kaḷku saistvielas ar pucolānu piedevām. Hidrauliskuma modulis $h m=(\mathrm{CaO}+\mathrm{MgO}) /\left(\mathrm{SiO}_{\text {zakt. }}+\mathrm{Al}_{2} \mathrm{O}_{3}+\right.$ $\mathrm{Fe}_{2} \mathrm{O}_{3}$ ) šīm saistvielām ir līdz 4,5. Vēsturiskās javas senatnes mūros pārsvarā ir korodējušas mitruma migrācijas ietekmē, jo parasti ir izskalota saistviela. Mūru sabrukšana arī ir notikusi sālsu destruktīvās iedarbības rezultātā. Vēsturiskajās javās saistvielas un pildvielas attiecība lielākoties ir robežās no 1:1 līdz 1:4, tās ir gan treknas, gan liesas. Kā pildvielas šajās javās ir lietotas rupjas smiltis un grants. Pildvielās vairāk nekā 60 \% graudu izmērs $0,5-1 \mathrm{~mm}$, bet $20-30 \%$ graudu izmērs ir $0,2-0,5 \mathrm{~mm}$ [13], [14]. 


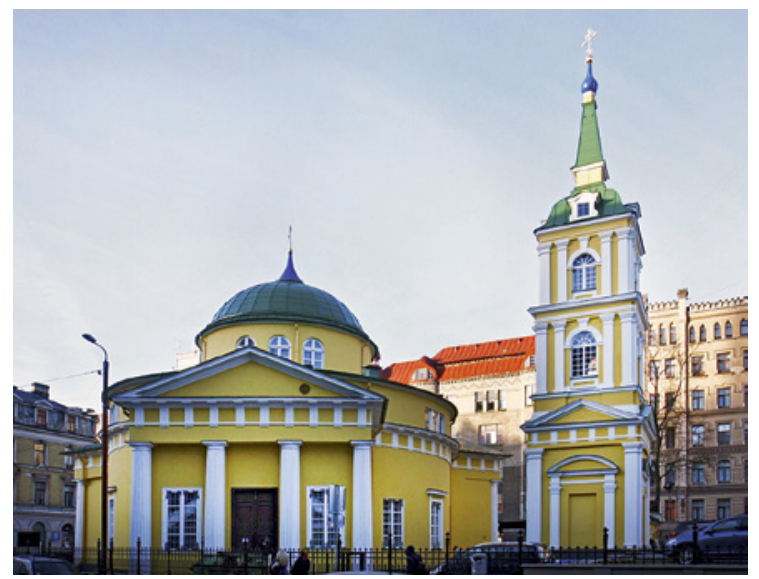

Vēsturisko mūrjavu ilgmūžības nodrošināšana Latvijas senatnes būvēs

1. att. Svētā Aleksandra N̦evska baznīcas zvanu tornis, Brīvības 56, Rīga. Torṇa karnīzes restaurācijai 20. gs. trīsdesmitajos gados izmantoja blīvu cementa javu, un rezultātā zem tās esošās vēsturiskās porainās javas sairst.

\section{Mūrjavu ilgmūžības nodrošināšanas pamatprincipi}

Tikai pēc zinātniskā izpētē iegūtajiem rezultātiem var izvēlēties autentiskus restaurācijas un konservācijas materiālus un metodes. Apkopotie rezultāti un RTU Akmens materiālu konservācijas un restaurācijas centra pētnieku pieredze parāda, ka vēsturisko objektu celtniecībā Latvijā lietoti dolomīkal̦ḳi un baltkal̦ k̦i, kas iegūti no mālus saturošiem (merǵel̦ainiem) dolomītiem un kaļ,kakmen,iem. Tas nozīmē, ka šie kal̦ki saturēja hidrauliskās komponentes un mūrjavas bija mitruma un mehāniski izturīgas, jo nelielā daudzumā, mūrējumam cietējot, veidojās cementa minerāli [1], [15], [16].

Šādu vēsturisko mūru restaurācijai iesakāmi dolmītkal̦ k̦i (dažkārt arī baltkal,ki) ar 5-15 \% cementa piedevu, kas nodrošina mūrjavu hidrauliskumu (mitruma un mehānisko izturību), bet ne tīras cementa javas.

Portlandcements (kaut arī tas ir plaši lietots celtniecībā) restaurācijas mērḳiem nav piemērots tā lielā blīvuma, zemās elastības, augstā sāḷu satura un no senajiem akmens materiāliem atšķirīgā ķīmiskā un mineraloǵiskā sastāva dēḷ. Savukārt kal̦ku javas bez piedevām, kurām piemīt laba saderība ar novecojušiem vēsturiskiem materiāliem, nedrīkst lietot ārējās vides apstākḷiem pakḷautās vietās, jo tās nav izturīgas pret ūdens iedarbību (tām nepiemīt hidrauliskas īpašības) [17].

Lai novērstu šķīstošo sāļu radītos bojājumus mūros:

1) jālikvidē sāḷu rašanās avots (piemēram, jāizsūknē ūdens no pagraba, jānovērš atledošanai lietotā sāls kaisīšana ap mūri, jāaizvāc telpā esoši minerālmēslu vai citu sāḷu avotu krājumi); 
2) sausā veidā jāattīra izsāḷojumi no mūra, jāsavāc un jāaizgādā tie prom, lai nenotiktu to atkārtota ieskalošanās mūrī;

3) maksimāli jānovērš mitruma migrācija (jāsalabo lietusūdens sistēma, jumts, notekcaurules). Jebkāda veida centieni ūdeni "iesprostot", noklājot materiālu no ārpuses ar ūdensnecaurlaidīgiem materiāliem (piemēram, blīvām flīzēm, plāksnēm, blīvu cementa javu) radīs papildus bojājumus vēsturiskajam materiālam;

4) nepieciešamības gadījumā jāveic mūra atsāḷošanas pasākumi (izmantojot sanācijas sistēmas) [18].

Mūru atbrīvošana no tajos esošajiem sāḷiem veicama, izmantojot pieejamos sanējošo apmetumu sastāvus. Tās ir speciāli veidotas rehabilitācijas sistēmas, kuru galvenā sastāvdaḷa ir poraina grunts, kas aizkavē sāḷu kristalizēšanos uz jaunā apmetuma virsmas. Tā vietā sāḷ kristāli veidojas sanējošā apmetuma porās, kur paredzēta vieta to augšanai. Sanējošā apmetuma uzklāšana ir salīdzinoši vienkārša, taču tā jāveic precīzi, ir darbietilpīga un samērā dārga [19].

Pirms restaurācijas darbu uzsākšanas ieteicams izveidot eksperimentālos laukumus izvēlēto materiālu un metodes pārbaudēm. Tālāk seko mūra sagatavošana, javas iestrāde un uzklāšana, kur būtiska ir pareiza mitruma izvēle un javas cietēšanas režīma kontrole optimālā mitruma nodrošināšanai.

Jāatceras, ka arī ar pareizi izvēlētu restaurācijas materiālu sastāvu apmierinoši restaurācijas darba rezultāti nav iespējami, ja restauratoram trūkst zināšanu un pieredzes par javu iestrādes tehnologiju [20].

Pēc restaurācijas pabeigšanas obligāti ir jānodrošina atjaunoto objektu regulāra novērošana, kopšana un uzturēšana. Svarīgi atzīmēt, ka paveiktā darba kvalitāti lielā mērā ietekmē restauratora zināšanas, prasme, attieksme un spējas orientēties dažādās situācijās atbilstoši ètikas nosacījumiem.

\section{LITERATŪRAS SARAKSTS}

[1] L. Krāğe and I. Vītina, "Saistvielu izpēte Latvijas vēsturiskajās būvēs: ìss pašreizējā stāvokḷa raksturojums," In 7. Baltijas valstu restauratoru triennāles konferences materiāli, 2005, pp. 47-52.

[2] R. Kozłowski, D. Hughes, and J. Weber, "Roman Cements: Key Materials of the Built Heritage of the 19th Century," Materials, Technologies and Practice in Historic Heritage Structures, pp. 259-277, 2010. https://doi. org/10.1007/978-90-481-2684-2_14 
[3] Ю. Эйдук, and И. Гросвалд, “Развитие производства доломитового романцемента в России и на территории Латвийской ССР," Latvijas valsts P. Stučkas universitātes zinātniskie raksti, vol. 22, pp. 283-295, 1958.

[4] I. Grosvalds, No piramīdām līdz dzelzsbetonam. Rīga, USSR: Latvijas PSR

[5] I. Barbane, I. Vitina, and L. Lindina, "Synthesis of romancement from Latvia's clay and dolomite," In Proc. of 18. Internationale Baustfftagung IBAUSIL, 2012, pp. 749-755.

[6] R. Lusis, L. Krage, and I. Vitina, "The influence of air pollution on the monuments of Latvia," In Proc. of US-Baltic Workshop Environmental Chemistry, 1997, pp. 67-71.

[7] I. Vitina, O. Baumanis, E. Lagzdins, S. Igaune, I. Grosvalds, and L. Krage, "Corrosion and conservation of natural stone monuments in Latvia," Latvian Journal of Chemistry, vol. 3, pp. 367-374, 1994.

[8] R. Lusis, I. Sidraba, L. Krage, and I. Vitina, "Investigation of stone materials with view to restoration of stone Monuments in Latvia," In Proc. of the International Congress "Quarry-Laboratory-Monument", 2000, pp. 403-407.

[9] J. Svare, I. Vitina, R. Lusis, and L. Lindina, "Investigations of damages of stone materials caused by salts and moisture migration in Capithulum hall of Riga Dome Cathedral," In "EcoBalt-2007" konferences materiāli, 2007, p. 31.

[10] A. Klisińska-Kopacz, R. Tišlova, G. Adamski, and R. Kozłowski, "Pore structure of historic and repair Roman cement mortars to establish their compatibility," Journal of Cultural Heritage, vol. 11, no. 4, pp. 404-410, Oct. 2010. https://doi.org/10.1016/j.culher.2010.03.002

[11] A. Palomo, M. T. Blanco-Varela, S. Martinez-Ramirez, F. Puertas, and C. Fortes, "Historical Mortars: Characterisation and durability. New tendencies for research," In ARCCHIP European research on Cultural Heritage. State-of-the-Art studies, 2004, pp. 167-184.

[12] J. M. Teutonico, Laboratory Manual for Architectural Conservators. Rome, Italy: ICCROM, 1988.

[13] S. Igaune, I. Vitina, I. Timma, and L. Lindina, "Compatibility of historical stone materials of Kuldiga brick-vault bridge across the Venta river and materials used in the restoration of the bridge," Chemine Technologija, vol. 51, no. 2, pp. 22-29, 2009.

[14] S. Igaune-Blumberga, I. Vitina, L. Lindina, and I. Timma, "Investigation of stone materials at the Riga Stock Exchange building," In Proc. of BaltSilica 2011, 5th Baltic Conference on Silicate Materials, 2011, pp. 67-68.

[15] S. Igaune-Blumberga, I. Vitina, and I. Timma, "Methods and materials for conservation of Power tower of Daugavgriva's fortress," In Proc. of the $9^{\text {th }}$ Baltic States Triennial restorers'meeting, 2011, pp. 253-254.

[16] L. Krage, I. Vitina, L. Mickevica, and S. Lagzdina, "The Research of Historical Binders of Rauna Castle (Latvia) Motivated for Restoration," In Proc. of 16. Internationale Baustfftagung IBAUSIL, 2006, pp. 1257-1264. 
[17] I. Barbane, I. Vitina, and L. Krage, "Low-temperature Hydraulic Binders for Restoration Needs," Materials Science and Applied Chemistry, vol. 28, pp. 5-9, Oct. 2013. https://doi.org/10.7250/msac.2013.001

[18] L. Krage, I. Kirilovica, I. Rozenstrauha, and I. Sidraba, "Carbonate Rocks Providing the Raw Material for Lime in Latvia," Materials Science and Applied Chemistry, vol. 26, pp. 82-87, 2012.

[19] J. Svare, I. Vitina, L. Krage, and R. Lusis, "Working Efficiency of "Sacrificial" Plasters - Practical Experience in Latvia," Materiālzinātne un lietišksā kìmija, vol. 17, pp. 68-74, 2008.

[20] I. Kiriloviča, "Hidrauliskas javu saistvielas izstrāde dolomīta romāncementa objektu restaurācijai," Doctoral thesis, Riga Technical University, Rìga, Latvia, 2016.

Inta Kiriloviča - Dr.sc.ing. (2016). MLĶF Silikātu materiālu institūta Akmens materiālu konservācijas un restaurācijas centra pētniece. Kopš 2008. gada strādājusi akmens materiālu restaurācijas jomā. Galvenie darba virzieni ir vēsturisku saistvielu kīmiskā analīze, akmens materiālu korozijas procesu izpēte un jaunu javu saistvielu sintēze restaurācijas mērḳiem.

Adrese: P. Valdena iela 3/7, Rīga, LV-1048

E-pasts: inta.kirilovica@rtu.lv

Margarita Karpe - Mg.sc.ing. (2006). MLĶF Silikātu materiālu institūta Akmens materiālu konservācijas un restaurācijas centra vadītājas p. i. Galvenie darba virzieni - vēsturisku saistvielu ḳīmiskā analīze, akmens materiālu korozijas procesu izpēte un dažādu materiālu (smiltis, dolomīts, māls u. c.) kīmiskā analīze.

Adrese: P. Valdena 3/7, Rīga, LV-1048. Tālr. 28887157.

E-pasts: margarita.karpe@rtu.lv

Inta Vītiṇa - Dr.sc.ing. (1992). MLĶ̧F Silikātu materiālu institūta Akmens materiālu konservācijas un restaurācijas centra vadošā pētniece. Galvenais darba virziens - Latvijas kultūrvēsturisko objektu akmens materiālu izpēte, akmens korozijas pētījumi, restaurācijas procesu pārraudzība. Vairāk nekā 130 zinātnisku publikāciju autore.

Adrese: P. Valdena 3/7, Rīga, LV-1048

E-pasts: vitina@ktf.rtu.lv

Silvija Igaune-Blumberga - MLĶF Silikātu materiālu institūta Akmens materiālu konservācijas un restaurācijas centra pētniece, silikātu materiālu ķīmiskās analīzes speciāliste. Galvenie zinātniskā darba virzieni - akmens materiālu analīzes un korozijas procesu pētīšana.

Adrese: P. Valdena iela 3/7, Rīga, LV-1048

E-pasts: igaune@ktf.rtu.lv 
Inta Kiriloviča, Margarita Karpe, Inta Vītina, Silvija Igaune-Blumberga.

\section{Ensuring the Permanence of Historical} Mortars within Buildings of Latvia.

Keywords - lime, corrosion, mortar, restoration, Roman cement, binder, salts.

Since 1984 research on corrosion of cultural heritage buildings of Latvia has been conducted in the Centre of Restoration and Conservation of Stone Materials, Institute of Silicate Materials, Riga Technical University. This research provides a wide collection of materials and experience in ensuring the permanence of historical buildings. Accurate investigations must be a fundamental part of the restoration technology of each object. The acquired experience has given valuable knowledge about the aspects of use of different binders (Portland cement, lime etc.) in restoration processes.
Vēsturisko mūrjavu ilgmūžības

nodrošināšana

Latvijas senatnes būvēs 